\title{
The Impact of Job Stress on Employee's Performance at one of Private Banks in Egypt during COVID-19 Pandemic
}

\author{
Ashraf Elsafty ${ }^{1}$, \& Lydia Shafik ${ }^{2}$ \\ ${ }^{1}$ DBA., MBA., BSc., Adjunct Assistant Professor, ESLSCA University, Egypt \\ ${ }^{2}$ MBA candidate, ESLSCA University, Egypt \\ Correspondence: Ashraf Elsafty, DBA, MBA, BSc., Adjunct Assistant Professor, ESLSCA University, Egypt. \\ Lydia Samy Shafik, MBA candidate, ESLSCA University, Egypt.
}

Received: December 7, 2021

Accepted: January 7, 2022

Online Published: January 18, 2022

doi:10.5539/ibr.v15n2p24

URL: https://doi.org/10.5539/ibr.v15n2p24

\begin{abstract}
Job stress is a universal element that is not only encountered in every individual but also in every organization regardless of its size. Especially, bankers who are under a good deal of stress because of the nature of their work. Stress could result in a decrease in employees' performance, productivity, quality of labor, and high turnover rate, in addition to some health problems like anxiety, depression, and headache. The purpose of this paper is to investigate the perception of employees of one of the private banks in Egypt and their performance in the presence of job stress in the uncertain period of the coronavirus pandemic. The literature review defined the job stressors which are role ambiguity, underutilization of skills, and work overload. Similar studies have been also mentioned for the impact of job stress on employees' performance in different countries. A descriptive research design was conducted using a survey questionnaire that is distributed among the employees of the bank in all departments and the collected responses were 51 respondents that were taken from a total population of 1,100 employees. The questionnaire is divided into two parts; the demographic profile and the questions related to variables under study. Descriptive statistics are used and the study revealed that the job stressors "role ambiguity and underutilization of skills" has no impact on employees' performance in the banking field in Egypt. However, it is found that work overload has an impact on employees' performance and even more in the covid-19 era.
\end{abstract}

Keywords: employee performance, job stress, role ambiguity, underutilization skills, work overload, COVID-19, banks, Egypt

\section{Introduction}

Nowadays, with the modern lifestyle, stress became a well-known phenomenon worldwide that has a bad impact on individuals' health as well as on their performance whether personal or professional (Madian, Abdelaziz, \& Ahmed, 2019). Stress exists in every organization regardless of its size, this could be due to an unforeseen work environment, high competition, sustainability risk, and being forced to achieve certain standards with limited resources (Muda, Rafiki, \& Harahap, 2014). Accordingly, workplace stress emerges where employees are stressed to achieve their goals and objectives, spend more time at work, get pressured, and are not sure of what is expected from them to achieve, et. (Jamshed, Khan, Haq, Arif, \& Minhas, 2011).

The health Safety Executive UK (HSE) has defined stress as the opposite reaction individual has to extreme pressure, which can result in psychological and physical ill-health (HSSE, 2001). The Health Safety Security and Environment world HSSE add that for employees to be under pressure it could have a positive or negative impact depending on whether the individual can manage the stress or not, especially when demands and pressure become excessive (Bower, 2016) ( Bashir \& Ramay, 2010). Accordingly, stress could result in a significant impact on the employee's job performance (Shahid, Latif, Sohail, \& Ashraf, 2010). Also, stress can affect employee work efficiency, employee turnover, absenteeism as well as some health problem as anxiety, depression, headache, and backache (Shahid, Latif, Sohail, \& Ashraf, 2010).

According to a Bloomberg study "the most stressful country in which to live" in 2016, it was found that Egypt ranked the 15th of the 74 countries under study (Bower, 2016). In 2019, Egypt ranked 35 out of 142 countries in Atlas and Boots (boots, 2019). This shows that Egypt encounters a high level of stress in its lifestyle which reflects definitely on the workplace (Bower, 2016). 
One of the major sectors that suffer from job stress is the banking sector (Rizwan, 2014). The reasons are that bankers are always under a great deal of stress as a result of a large amount of time they spend at work, overtime to perform the requirements, loads of responsibilities, role ambiguity, role conflict, coping with the rapid change of technology, and physical environment at workplace, these all factors are continuously affecting employee's ability to cope and survive in the banking sector environment ( Bashir \& Ramay, 2010).

In addition, the evolution of coronavirus disease and the declaration of the WHO that it is a pandemic on 11 March 2020 had a great impact on every aspect of life (WHO, 2020). In the banking sector, it has resulted in a lot of changes in organizations' environments, the work structure itself as work from home strategy, the challenge of a work-life balance as well as the inability to cope with the new technology. Thus, needless to say, that a lot of employees are getting stressed not only afraid of getting infected but also, they are not able to cope with these- changes and start to feel insecure in their positions.

Thus, it is necessary to investigate and identify the factors that result in employees stress in Egypt and suggest methods to mitigate them. In addition, it is important to study the perception of employees and their performance in the presence of job stress, especially in such an uncertain period as the COVID-19 era. The reason is that stress must be managed by both individual and organization otherwise it could lead to a critical management dilemma or could affect the achievement of the organization.

According to Elsafty $(2018,2019,2020,2021)$ the contextual problem can be analyzed using a 9-element model which helps in understanding and integrating all sides of the research problem includes research organisation, management level, business functions, internal \& External environmental aspects, industrial field and the geographical location we can explore all of this element within the time scale (Elsafty \& Tahon, 2021) as shown in figure 1 below.

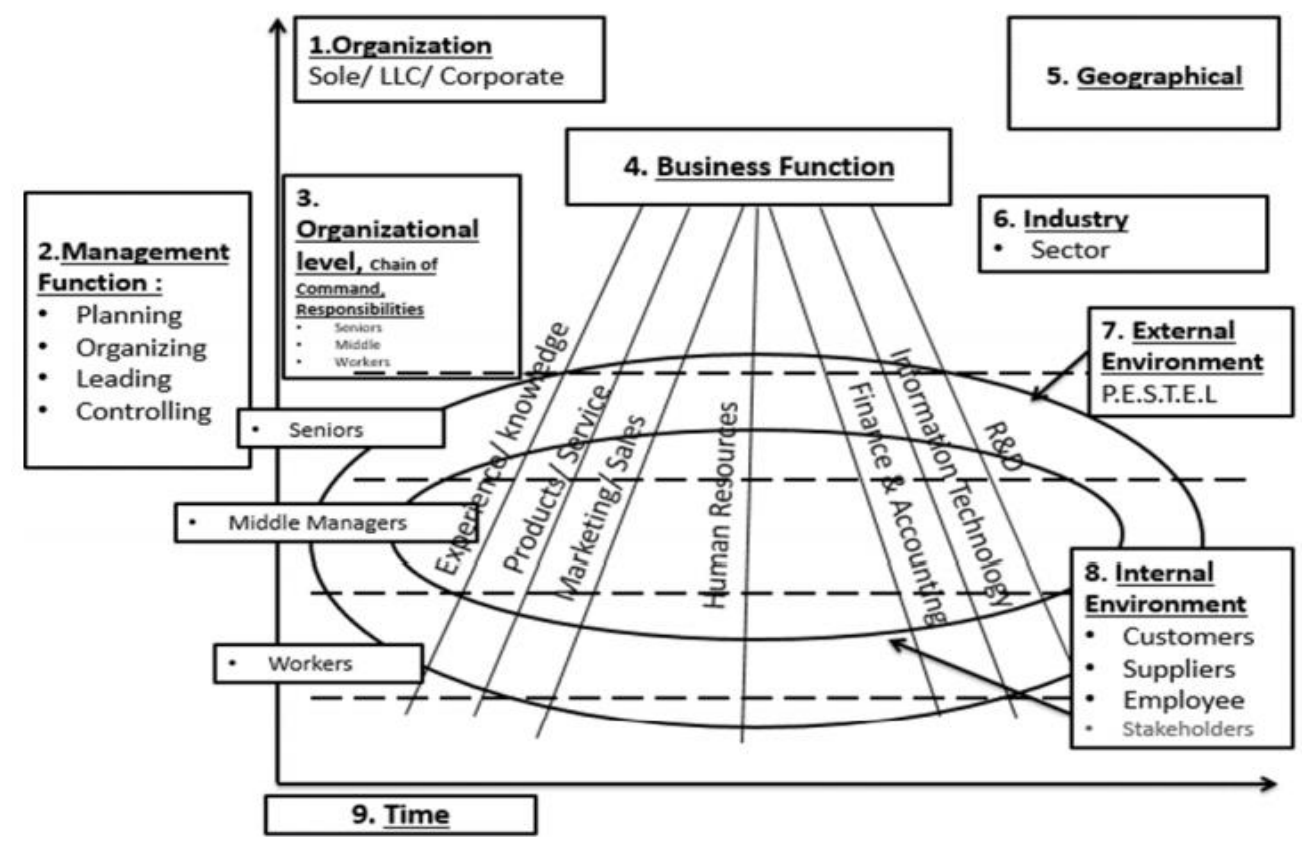

Figure 1. Business Anatomy: The 9 Elements Model Proposed by Elsafty (2018)

Several research publications have made use of the nine-element structure (Elsafty, Elsayed, \& Shaaban, 2020; Elsafty \& AlNawaly, 2020; Elsafty \& Ragheb, 2020/2021; Elsafty \& Abadir \& Sharawy, 2020; Elsafty, A., Elbouseery, I., \& Shaarawy, A., 2020; Elsafty, A., \& Elzeftawy, A., 2021; Elsafty, A., \& Elshahed, M., 2021; Elsafty, A., \& Osman, M., 2021; ). Using the nine elements mode Elsafty (2018, 2019, 2020, 2021), a stakeholder analysis was conducted with several employees in the Management information system (MIS) and market risk department, as well as random questions, have been asked to random ten employees in various departments in the bank. Some employees have mentioned that at the beginning of the COVID- 19 era employees were more stressed than before as a result of the uncertainty of the future and the new work from home policy yet as they get used to the new technique of work they performed better. They mentioned that the reason is they had a better work-life balance as they had more time to spend with their families. However, they 
still feel uncertain and stressed due to the new management and acquisition undergoes now as well as the unusual work overload that pushes them to do extra work that is not of their responsibility. In addition, a meeting was performed with the head of the market risk and head of risk control in the bank and they mentioned that work-life balance is rare as you go higher in the managerial levels as their responsibilities increase; they have to work at any time and take immediate actions as necessary. However, work overload is a real stress factor yet it is all about managing it. Also, they mentioned the changes in structure and the bank acquisition is making them feel unsecured of the new structure or the way they are going to manage the new Islamic bank products. A meeting with five HR employees was conducted and random questions were asked about what they think could affect the performance of employees or could increase their level of stress? They stated that time pressure and work overload especially in the period of coronavirus pandemic. They also mentioned that some departments' lack of manager's support and underutilization of employee's skills are other factors that act as an employee stress booster.

Employees are an important asset in the organization, and their performance is one of the crucial success determinants. According to Anitha J., employee performance is a combination of the financial or non-financial outcomes of the employees, that can directly be reflected on the organization's performance and success (J., 2014). Employee job performance is the degree of activity that the individual has to achieve the task successfully (Foster, 2002). Moreover, Jalagat (2017) mentioned that employee job performance is the outcome of the person's contribution to the organization in which the organization may evaluate as constructive or destructive (Jalagat, 2017).

Stress was defined by Robbins, Coutler, Sidani, and Jamila as is the opposing reaction individual have to extreme pressure placed on them from endless demands, constraints, or opportunities (Robbins, Coutler, Sidani, \& Jamila, 2011). According, to the Health, Safety, Security and Environment world (HSSE) employees can be affected by stress in both positive and negative ways, it could help in performance improvement for athletes, actors, or actresses (HSSE, 2001). However, the problem arises when the factors that cause stress became persistent and greater than the individual ability to cope with it or to perform the required tasks (Anderson, 2003). Thus, it's all about the ability of employees in managing stress, especially when demands and pressure become excessive, which could result in a significant impact on the employee's job performance (Bower, 2016) ( Bashir \& Ramay, 2010). Accordingly, job stress factors should be properly identified and analyzed as this is extremely crucial to be managed for both individuals and organizations (Chinyere, Ngige, \& Mojekeh, 2019).

The factors that result in stress are role ambiguity, underutilization of skills, and work overload. According to Robbins, Coutler, Sidani, and Jamila role ambiguity is when work expectations are hard to satisfy (Robbins, Coutler, Sidani, \& Jamila, 2011). It is when employees are confused and not sure of the way or method that the task is going to be performed with or when there is no clear instruction or clear responsibility of what is required from them (Jalagat, 2017). While Jalagat (2017) defined underutilization of skills as the skills and abilities that employees have that are beyond the required job to be performed (Jalagat, 2017) (Margolis, Kroes, \& Robert, 1974). Moreover, work overload is when the employees have a lot of responsibilities that exceed their capability of achieving them (Jalagat, 2017). Thus, Impractical deadlines or unrealistic expectations, and uncontrollable workloads will result in job stress even to the most capable employee.

The coronavirus pandemic (COVID-19) has worsened what was already there regarding the mental health problem in the workplace for years, it compounded the existing challenges (singh, 2020). On one hand, some people they found themselves unemployed and in a financial terrible, others are unsecured in their jobs as companies can do downsizing at any time to cut losses, on the other hand, those who were working from home are carrying challenges of their own (singh, 2020). Thus, with the increase in the level of stress during the pandemic dues to these conditions, it impacted significantly employees' performance and productivity.

Accordingly, the objective of this paper is to investigate the perception of the employees working in one of the private banks in Egypt and their performance which is the dependent variable of the study. Moreover, it will measure the presence of the job stressors which are role ambiguity, underutilization of employee's skills, and work overload on banker's performance especially in the uncertain period as COVID-19 which is the mediating variable.

Although, a lot of researchers worldwide have conducted this study on different sectors includes banking, only a few applied it to Egyptian employees. Those who studied the impact of stress on Egyptian employees were applying it to the nursing sector and none of them has studied the impact on employees working in banks or study the impact of coronavirus pandemic on employees' performance. Thus, this study will contribute to the science as it will study the perception of employees of one of the private banks in Egypt and their performance in 
the presence of job stress on one of Egyptian banks context which will lead to extra-scientific research studies in this field and it allows the practitioners to refer back to relevant science in this field which is rare to be affordable and to be available in developing countries as Egypt.

\section{Literature Review}

The job stress concept was highlighted in the 1990s where researchers started to focus more on occupational health and safety (Bower, 2016). According to the International Labour Organization, workplace stress is getting a very critical issue now than ever before, with the increase of global competition, difficulty in having a work-life balance, globalization that changed the nature of jobs, longer working hours as well as an increase in work pressure (Bower, 2016).

According to Chen and Silverthrone (2008), job stress is a psychological pressure that occurs related to the work that affects an employee's skills and ability to respond to a specific situation (JC \& C., 2008). Job stress is derived from excessive demands and pressure that exceeds an employee's ability to perform the given tasks. Thus, stress is supposed to be a complex and dynamic concept that can result in undesirable performance not only for employees by not working efficiently and effectively, but also it could reflect on the poor organization performance by not achieving its objectives (Chinyere, Ngige, \& Mojekeh, 2019).

During the Coronavirus pandemic period, it was found that stress was getting worse and it has affected the majority of employees worldwide (singh, 2020). It was found that almost $70 \%$ of American employees claim the COVID-19 is the most stressful time of their career, even more than what occurred in the great recession in 2008 (Mayer, 2020). Also, 88\% of employees were found to have moderate to an extreme level of stress in the first few months of the pandemic (Gavidia, 2020).

Accordingly, there are many factors that could result in job stress and could affect the level at which employees can perform their targeted tasks. One of the main stressors that affect employee performance is role ambiguity. Robbins, Coutler, Sidani, and Jamila (2011) have defined role ambiguity as the work expectations that are not easy to be fulfilled as they do not have any clear instruction or clear responsibility of what is required from them. When employees have abstrusely tasks with no clear guidance will result in a decline in employees' performance, a higher level of stress and an inability to meet their targets (Murali, Basit, \& Hassam, 2017). Many researchers found that role ambiguity has a negative impact on employee performance as a study conducted by Abu-Hussen, Abu-Salih, and Al Saket (2016) that was applied on Telecom Group (JTG) employees in Jordan as well as a study conducted by Murali, Basit, and Hassan in 2017 on employees selected from different sectors in Malaysia.

Another job stressor is the underutilization of skills, which was first introduced by Jalagat (2017). It was defined as the skills and abilities that employees have beyond the job requirements (Jalagat, 2017) (Margolis, Kroes, \& Robert, 1974). Jalagat (2017) found that it has a significant effect on employees' performance.

Needless to say, that Work overload is another factor that results in workplace stress. Work overload is when employees have excessive responsibilities to achieve the job assigned to them or the endless tasks that are beyond their ability or more than what the employee can bear (Jalagat, 2017). Many studies found that work overload can hinder employees' performance as Abu-Hussen, Abu-Salih, and Al Saket (2016) as well as the study conducted by Jalagat in 2017. However, Murali, Basit, \& Hassam (2017) found that work overload has no significant impact on employees' performance working in different sectors in Malaysia.

The job stressors are not limited to these above-mentioned factors; however, they differ by the change in the circumstances, industry, and even the country where the study is conducted in. As a result, several researches researched and analyzed the influence of job stress on employee performance in in different sectors and in different countries.

For example, a study conducted in Jordan by Abu-Hussen, Abu-Salih, and Al Saket (2016) was applied to Jordan Telecom Group (JTG) employees. The job tress factors examined in this research were: work overload, role conflict, role ambiguity, and physical conditions of work, while the dimensions of job performance were: Job Commitment, Job Loyalty, Functions Accomplishment, and Job Discipline as shown in the conceptual model below in figure (2) (Abu-Hussein, Abu-Salih, \& Al Saket , 2016). The study found that job stress factors are negatively affecting the performance dimensions under study, which were consistent with the findings of Bashir \& Ramay (2010), M.Kotteeswari \& Sharief( 2014), and Sabir, Akhtar, Zakir, Nadeem, \& Rehman (2014). 


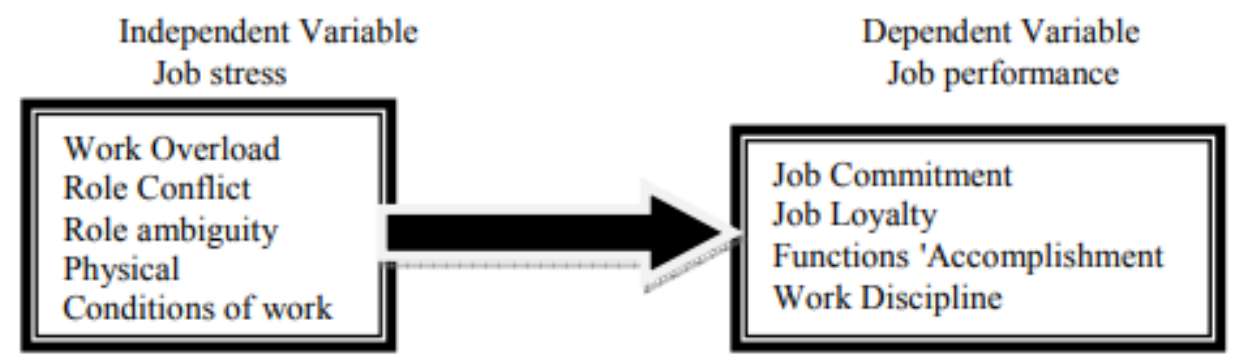

Figure 2. Conceptual Model (Abu-Hussein, Abu-Salih, \& Al Saket, 2016)

Murali, Basit and Hassan created a framework that helps in analyzing the impact of job stress and employee performance of employees selected from different sectors in Malaysia. This model focused on time pressure, work overload, lack of motivation and role ambiguity as shown below in figure (3). It found that time pressure and role ambiguity are negatively affecting employee performance, however, work overload and motivation have no significant impact (Murali, Basit, \& Hassam, 2017).

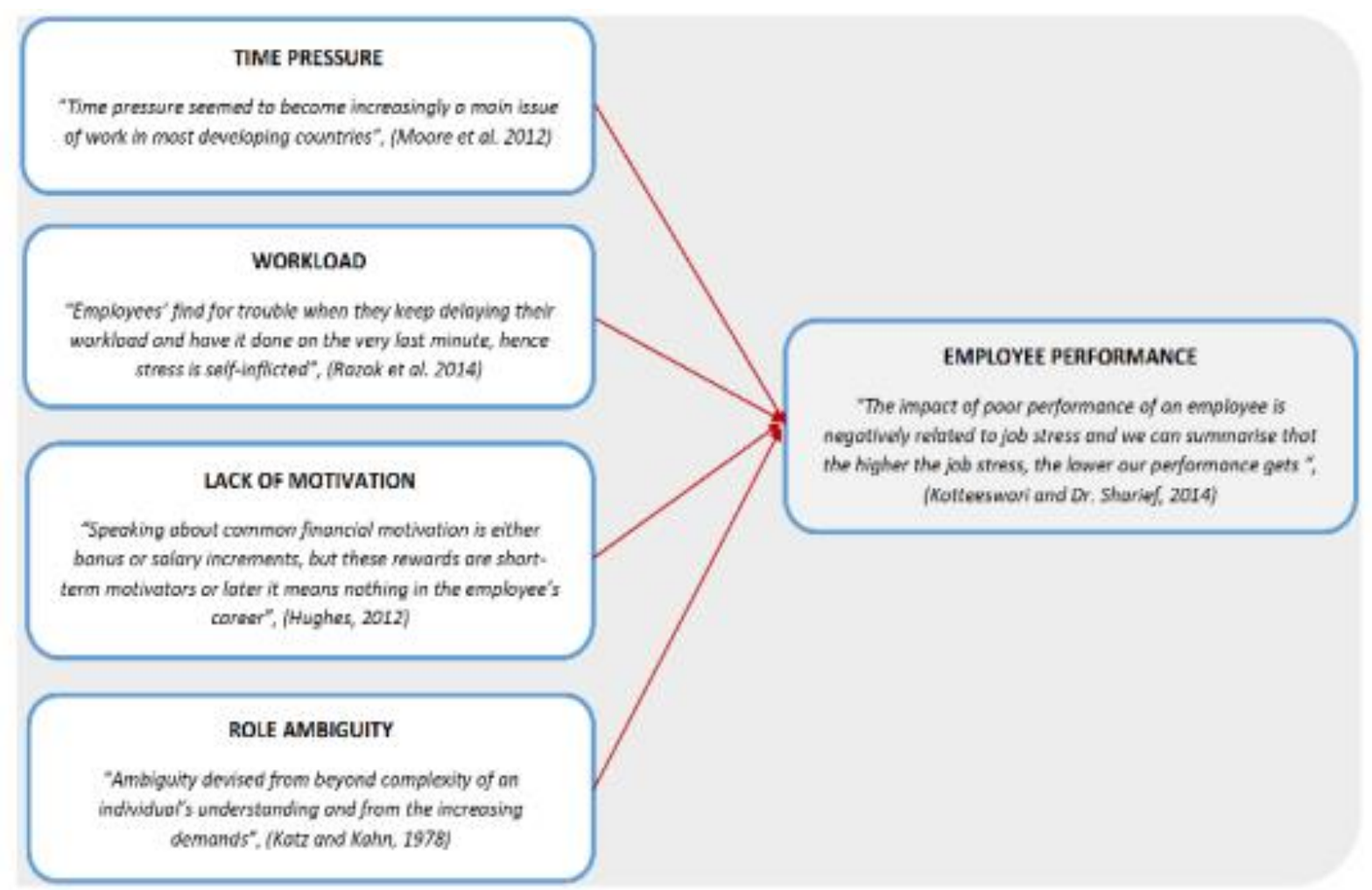

Figure 3. Conceptual Model (Murali, Basit, \& Hassam, 2017)

Revenio Jalagat (2017) argued that stress is one of the common difficulties that employees experiences on regular basis in their workplace, which could affect their mental and physical health. Accordingly, Jalagat (2017) conducted a study to examine the determinants of job stress and their impact on employees' performance of Petroleum Development Oman (PDO) in Al-Bahja Center. The job stressors examine in this research were: Job Ambiguity, underutilization of skills, and work overload as shown in the conceptual model in figure (4) below (Jalagat, 2017). The survey questionnaires were employed in a descriptive research design for the study, concluded that there was a significant relationship between job stress and employee performance where underutilization of skills and work overload significantly correlates to employee performance (Jalagat, 2017). 


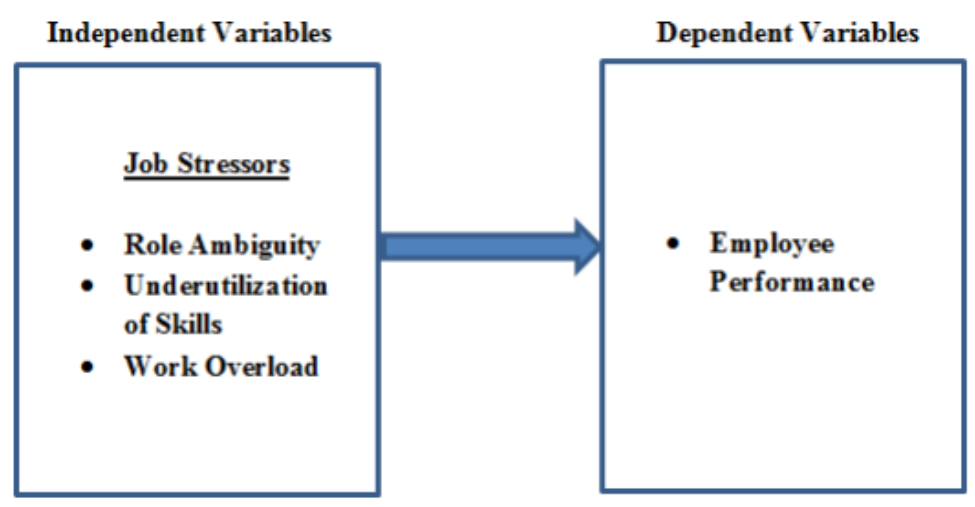

Figure 4. Conceptual Model (Jalagat, 2017)

For many years, the banking sector has been through enormous changes in organization and structure, as a result of emerging technologies and new types of jobs created that reshaped the working conditions and led to a continuous change in employment (Giorgi, et al., 2017). In addition, the increase of the market competition between national and international banks and the implementation of economic plans -like in Egypt those implemented by the Central Bank of Egypt- have placed great pressure and stress on banks and consequently bankers as well as their performance (Silva \& Barreto, 2012). Moreover, according to Pandey (2020), the competition level in the financial sector is very intense accordingly employees are pressured to provide a long-term relationship with customers, provide an outstanding service to have a competitive advantage in order to avoid losing their customer base.

Accordingly, the banking sector is considered to have a high-stress environment across the globe compared with the other sectors (Pandey, 2020). Many researchers found workplace stress is critical in the banking sector and resulted in a potential negative impact not only on employees' mental, psychological and physical health but also on the organization as a whole (Giorgi, et al., 2017). Thus, researches were conducted on the banking sector to examine and evaluate the impact of job stress on the performance of employees.

Muhammad Naeem Shahid, Khalid Latif, DR. Nadeem Sohail, Muhammad Aleem Ashraf (2010) conducted a study in Pakistan. The study examined six constituents of job stress "lack of administrative support, excessive work demand, problematic customer relations, coworker's relationship, family and work-life balance and riskiness of job" and examined their impact on bankers' performance in the district Faisalabad (Shahid, Latif, Sohail, \& Ashraf, 2010). They found that all the components of stress, are negatively related to employee's performance (Shahid, Latif, Sohail, \& Ashraf, 2010). This is consistent with another study conducted in Pakistan by Usman Basher and Mohammed Ismail (2010) who concluded that job stress hinders employee performance and contributes in employee dissatisfaction. Also, they found that work overload and time pressure make bankers incapable of having a work-life balance which causes some serious social problems ( Bashir \& Ramay, 2010). They suggested that organizations should have a supportive culture within the working atmosphere by having appropriate strategies regarding working hours, interpersonal relations, and employee supervision in order to mitigate and manage workplace stress in banks ( Bashir \& Ramay, 2010).

In Indonesia in 2014, Iskandar Muda, Ahmed Rafiki and Martua Rezeki Harahap have conducted a study on Islamic banks. The study examined the important elements that influence employees' performance as job stress, communication, and motivation as shown in the conceptual model in figure (5) (Muda, Rafiki, \& Harahap, 2014). They found that job stress has no impact on "',"'” performance in Islamic banks in Indonesia (Muda, Rafiki, \& Harahap, 2014). They justified that Islamic banks implement policies that are away from excessive pressure and stress that may push the employees to do unethical actions (Muda, Rafiki, \& Harahap, 2014). 


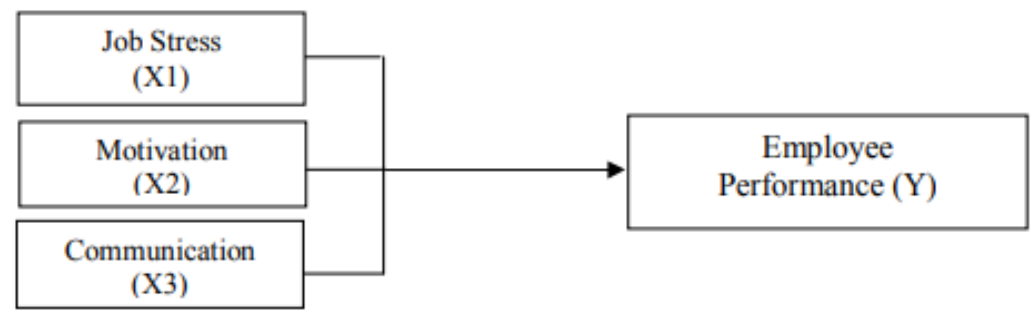

Figure 5. Conceptual Model (Muda, Rafiki, \& Harahap, 2014)

Moreover, Goswami (2015) has evaluated the impact of occupational stress on employees' performance of Banks in major cities of Rajasthan State through a structured questionnaire. They found that job stress results in poor mental and psychological health (Goswami, 2015). Thus, they recommended that banks should not only diminish the job stress and insecurity, but also the psychological stress factors (Goswami, 2015). This could be done through reducing job and role conflict as well as investing more in supportive activities such as behavioral and psychological counseling, in addition to organizing time and stress management workshops (Goswami, 2015)

Another study was conducted by Md. Hasebur Rahman on a commercial bank in Bangladesh (Rahman, 2013). The study showed that there is a positive relationship between stress and employees' performances; however, there is an adverse relationship between stress and the health of employees' well-being (Rahman, 2013). Moreover, it found that long working hours and workload are the top stressors of both public and private commercial banks in Bangladesh (Rahman, 2013).

In addition, Mbanefo Priscilla Chinyere, Prof. Chigbo D. Ngige, and Michael O. Mojekeh, conducted the same study on Selected Banks in Nigeria Mbanefo Priscilla (Chinyere, Ngige, \& Mojekeh, 2019). The study found that bankers' organizational skill is influenced by employees' work-life and family interface; on the other hand, there was no relation between management support and bankers' effectiveness (Chinyere, Ngige, \& Mojekeh, 2019).

Dhruba Lal Pandey (2020) has examined eight elements of job stress; "work type, salary pay scale, and job insecurity, poor communication, work overload, lack of motivation, lack of management support and poor performance evaluation and appraisal system" as shown in the conceptual model in figure (6) (Pandey, 2020). This study was conducted on bankers of Kathmandu valley the capital of Nepal and concluded that work overload was ranked the top reason of stress belongs to employees, then comes the lack of job security, poor communication, and work type (Pandey, 2020). The result was justified as Nepalese banks have a culture that works in a burden, not an opportunity to learn (Pandey, 2020). This was consistent with a study conducted in 2018 by Vijayan with a conceptual model in figure (7), who found that work stress has a negative relation to employees' performance and the most important job stressors were job insecurity, role conflict, and low pay (Vijayan, 2017).

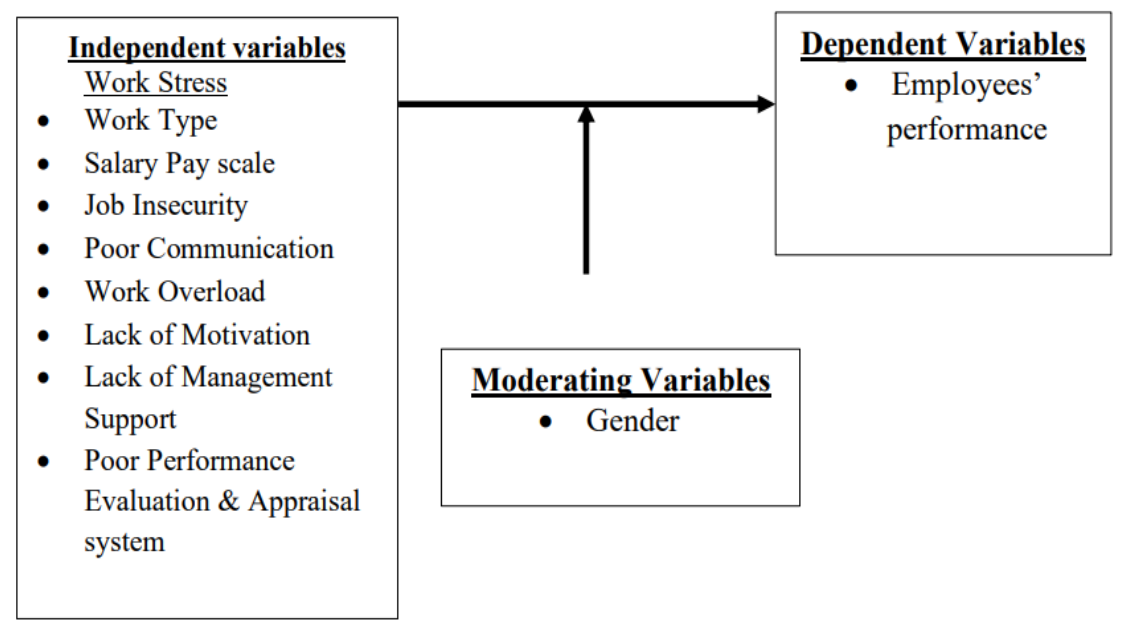

Figure 6. Conceptual Model (Pandey, 2020) 


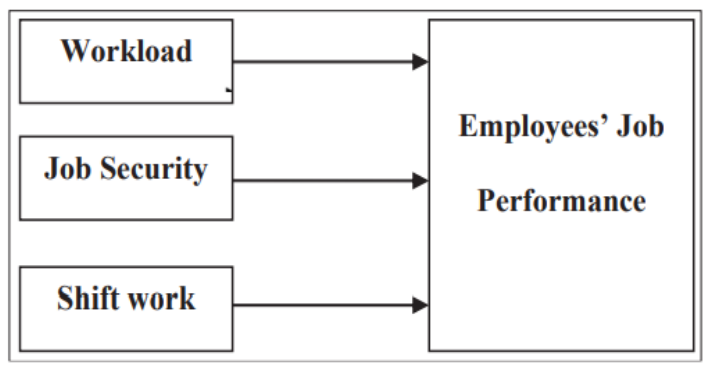

Figure 7. Conceptual Model (Vijayan, 2017)

Although Egypt was ranked in 2016 by Bloomberg in "The most stressful country in which to live", the 15th out of 74 countries under study (Bower, 2016), only a few studies were conducted on Egyptian employees to examine the job stress factors and only one study was applied on banking sector while two were on nursing sectors.

Madian, Abdelaziz, and Ahmed (2019) conducted research to examine the impact of stress on nursing students at Damanhour University in Egypt. They found that students are facing a moderate level of stress (Madian, Abdelaziz, \& Ahmed, 2019). While, Amr, El-Gilany, El-Moafee, Salama, \& Jimenez (2011) conducted another paper to examine and evaluate the level of stress among bachelor's degree Mansoura nursing students and to determine the possible factors. They found that students face high-stress levels, anxiety, and depression by $40.2 \%, 46.6 \%$, and $27.9 \%$ respectively (Amr, El-Gilany, El-Moafee, Salama, \& Jimenez, 2011). Accordingly, they concluded that stress management is recommended to be introduced in the nursing health of the university (Amr, El-Gilany, El-Moafee, Salama, \& Jimenez, 2011).

The only study that was conducted on the banking sector at Mansoura City in Egypt was by Salim, Wahed, Zidan, and Assad (2019) that was applied to employees working in national and private banks. They focused on evaluating the occupational job stress among Egyptian bankers and determining its risk factors (Salim, Abdel Wahed, Zidan, \& Aboal asaad, 2019). They found that about $22.8 \%$ of employees working in national banks showed higher levels of stress compared with only $12 \%$ in private banks (Salim, Abdel Wahed, Zidan, \& Aboal asaad, 2019). In addition, they concluded that there are statistically significant differences between employees working in national and private banks and recommend that interventions are needed to eliminate occupational stress among employees working in the banking sector (Salim, Abdel Wahed, Zidan, \& Aboal asaad, 2019). This study was only examining the level of stress among employees working in the banking sector; however, no research has studied the impact of that stress factors on Egyptian employees working in banks.

In conclusion, Job stress can be caused by a variety of circumstances. According to the literature, these factors could include but are not limited to: overload of work, role ambiguity, lack of administrative support, role conflict, conditions of work, physical, lack of motivation, communication, underutilization of skills, work-life balance, time pressure, the riskiness of job and others. However, they may vary depending on the situation and the circumstances, industry, and the country where the study is conducted. Moreover, it was found that Egypt is one of the countries that have a high level of job stress for many different reasons especially in the banking sector. However, only a few studies have addressed this and none of them has examined their impact on employees working in the banking sector.

\section{Methodology}

The theoretical framework is developed based on the aim of the study as well as the previous literature in this area. the model was developed based on a previous study conducted by Jalagat in 2017 who examined the impact of job stress on employees' performance of Petroleum Development Oman (PDO) in Al-Bahja Center that is shown in figure (8) (Jalagat, 2017). 


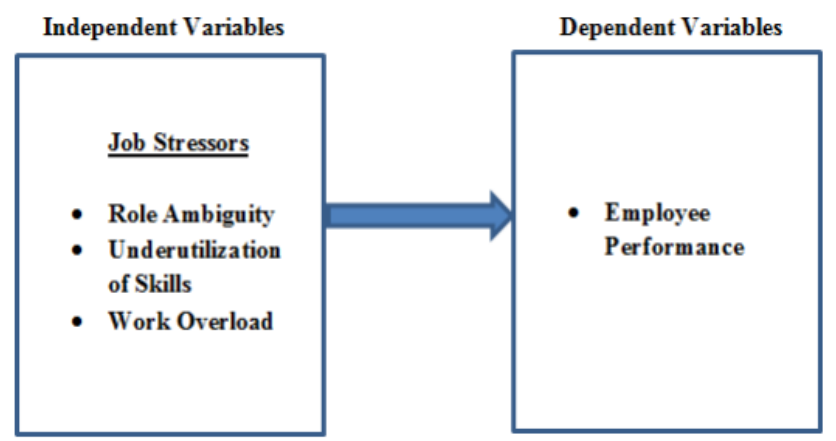

Figure 8. Conceptual model from the literature (Jalagat, 2017)

The Jalagat study aimed to identify job stressors that influence employee performance and investigate the link between these job stressors which is the independent variable and employee performance the dependent variable (Jalagat, 2017). This model was chosen as it contains the most relevant factors to this study which are role ambiguity, underutilization of skills, and work overload, adding only one more variable which is the effect of COVID-19 the mediating variable on job stressors and its impact on employee's performance. Accordingly, the new conceptual model has been developed as shown below in figure (9).

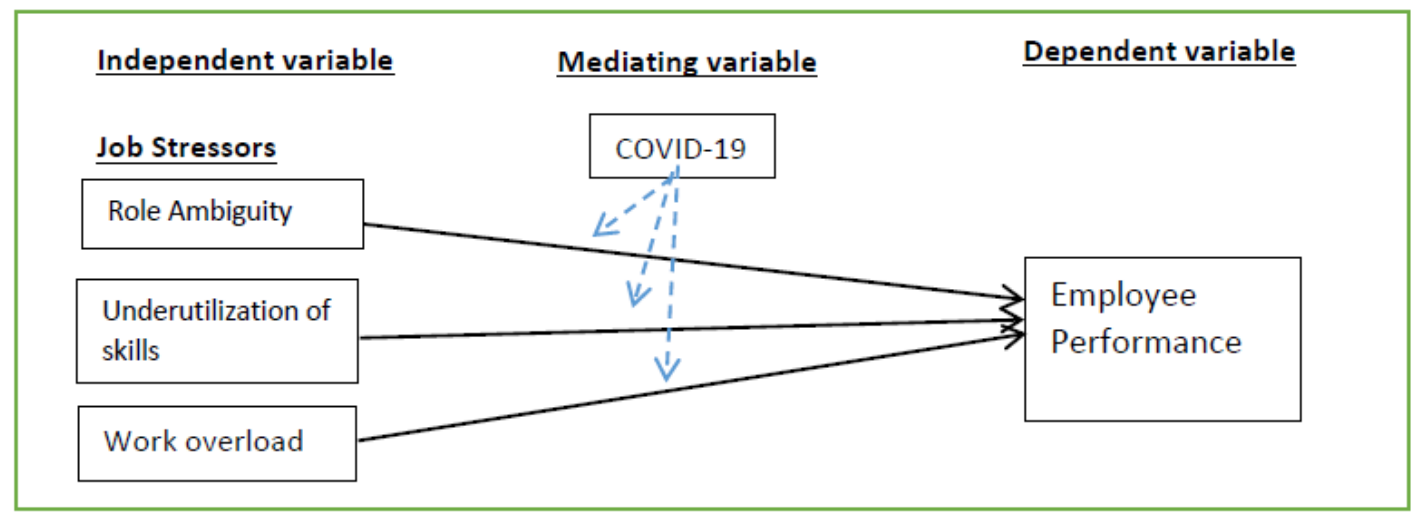

Figure 9. Research theoretical framework

This research model represents and fulfills the purpose of the study where the dependent variable is the perception of the employees working in one of the private banks in Egypt and their performance, while the independent variable is the presence of the job stressors in banker's environment which are role ambiguity, underutilization of employee's skills, and work overload, especially in the uncertain period as COVID-19 which is considered the mediating variable. This research is quantitative research with a descriptive research design and the type of investigation is moderate -contrived research as the researcher will use a model that was previously conducted in the literature by Jalagat (2017) adding only the meditating variable which is the effect of COVID -19 era on job stressors and their impact on employee's performance.

The questionnaire is used in data collection as it helps in gathering a large number of quantitative data, as it can be sent to respondents electronically via email, and responses will be easily collected and analyzed. The questionnaire is divided into two parts. The first part of the questionnaire focuses on the demographic profile of the respondents as for example the employees' gender, age, educational level, position in the bank, and years of experience in the banking sector. While the second part of the questionnaire presents the questions as presented by Jalagat (2017) in addition to the questions related to the mediating variable COVID-19 attached appendix (A). The measuring scale used is the Likert Scale model in the form of (5) Strongly Agree; (4) Agree; (3) Neither Agree/Disagree; (2) Disagree; (1) Strongly Disagree. The data is collected and analyzed using the descriptive statistical tool to determine the impact of the job stressors on employee performance in one of the private banks in Egypt. 


\section{Data Analysis}

The data has been analyzed using descriptive techniques such as frequencies, percentages, means, and histograms to describe the collected responses. Firstly, a preliminary unstructured interview has been conducted with different experts in the banking field in order to validate and enrich the proposed model. At the same time, the questionnaire has been distributed in order to measure and analyze each variable under study. The survey is distributed among the employees of the bank in all departments and the collected responses were 51 respondents that were taken from a total population of 1,100 employees.

Female respondents represented the majority with $56.8 \%$ while the male represented only $43.14 \%$ of the total sample; most of the participants were holding master's and bachelor's degrees. The majority of participants were between the ages of 30 and 39, with a rate of 59\%, 29\% were in the rage of 20-29 years and $12 \%$ were more than 40 years. The results showed that more employees are in their middle ages. While regarding the years of experience, $37 \%$ of respondents had 10-20 years of experience in the banking field, $29 \%$ had 0-5 years of experience, $25 \%$ had 6-10 years and only $8 \%$ had 20-30 years of banking experience. This variation ensures having a wider perspective of respondents.

The second part of the questionnaire were discussing the Job stress that is considered a challenge in the banking sector, especially in Egypt.

Regarding the first variable which is role ambiguity as shown in figure (10), the results showed that on average $37 \%$ of the respondents disagreed that stress could occur when employees do not have a clear role or responsibilities of what is required from them, while only $31 \%$ were agreed. This shows that there is a likelihood of disagreement that the job stressor "role ambiguity" has an impact on employees' performance in the banking field. Bankers see that their departments have clear goals and they always have well-defended procedures to follow. Moreover, it is easy to establish a clear path for their career.

It is also found that for the second variable which is underutilization of skills as shown below in figure (11), 36\% of respondents disagreed that it increases job stress or negatively affects their performance in the bank. Bankers believe that they can improve their knowledge and skills as long as they are working in the bank. On the other hand, $24 \%$ of respondents agreed that underutilization of their skills increases their job stress and does not give them the chance to improve their performance. Thus, this shows that there is a likelihood of disagreement that the job stressor "underutilization of skills" has an impact on employees' performance in the banking field.

Regarding the third variable which is work overload as shown below in figure (12), it is found that $43 \%$ of respondents agree with another $16 \%$ strongly agree that stress could occur when employees are overloaded with work that exceeds their capabilities and affects their performance. It is found that bankers accept any new tasks assigned to them even if they feel tired and overloaded only to maintain a high level of performance. This suggests that as a result of the loads of work in the banking field on daily basis, employees have the feeling that they are assigned to too many tasks that exceed their capabilities, thereby impacting their performance, and wind up with exhausting. Thus, this shows that that work overload has an impact on employee performance in the banking field.

In analyzing the impact of role ambiguity on employees' performance as a result of Covid 19 , it is found that $41 \%$ of respondents do not agree that their role ambiguity has changed or caused more job stress in the banking field because of the pandemic of coronavirus as represented in figure (13) below. They kept doing the job as it is, by sticking to the bank procedures and clear goals. Moreover, it is found that $41 \%$ of respondents are neutral to the impact of underutilization of their skills on their performance in the coronavirus pandemic era as represented in figure (14). However, in figure (15) $47 \%$ of respondents are agreed that work overload has an impact on employee's performance in this very stressed period of the pandemic. Employees believed that they are overloaded with work that exceeds their capability of executing which has an influence on their performance in this period. This can be interpreted as in the Covid-19 era the employment rate is too low, thus employees have the tendency to accept any extra task or any job even if it is too stressful or beyond their capability. 


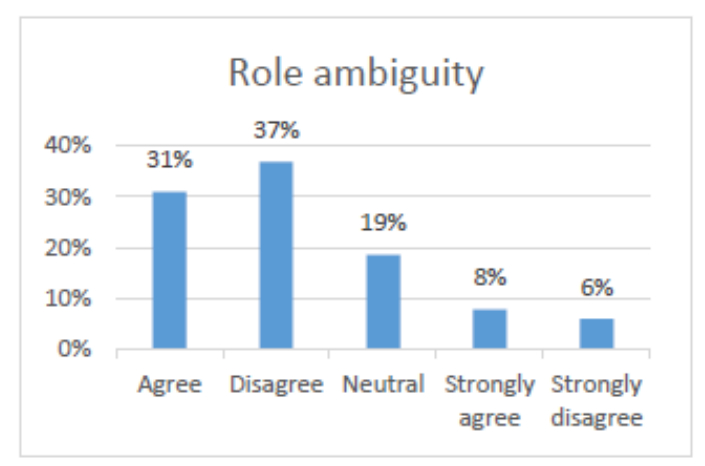

Figure 10. Role ambiguity analysis

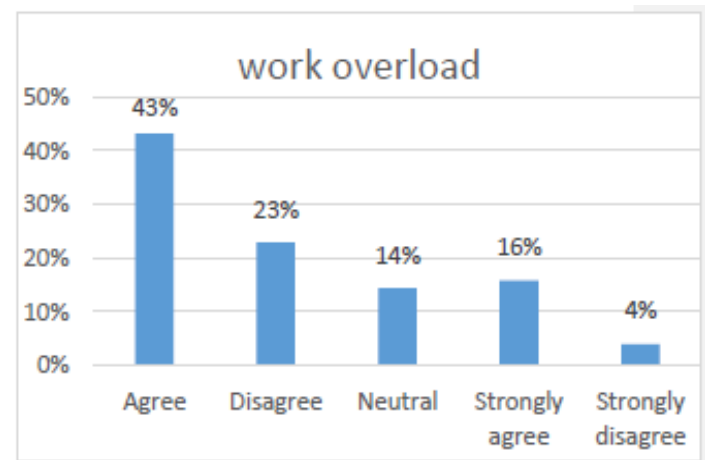

Figure 11. Work overload analysis

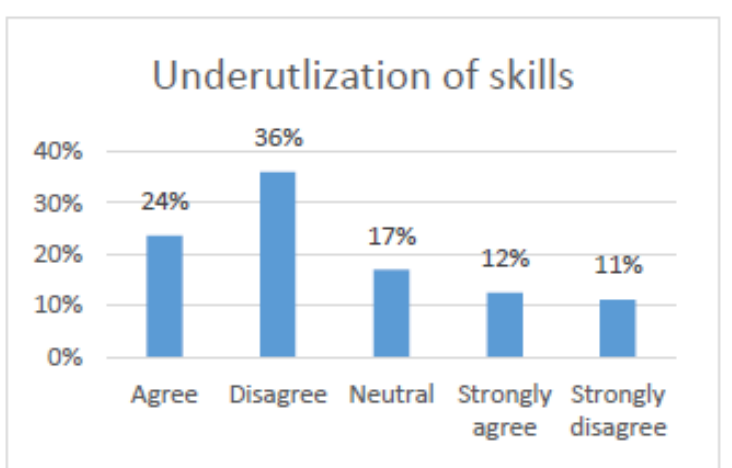

Figure 12. Underutilization of skills analysis

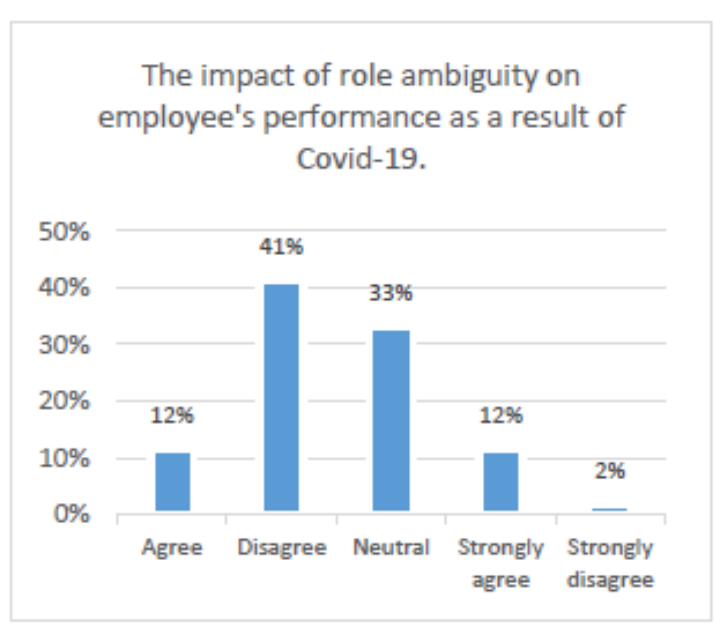

Figure 13. The impact of role ambiguity on employee's performance as a result of Covid-19 analysis 


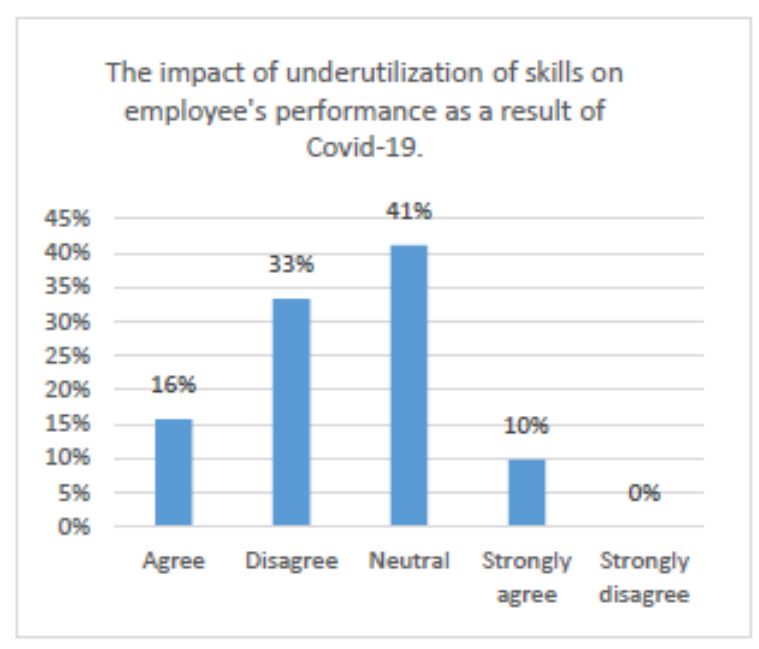

Figure 14. The impact of underutilization of skills on employee's performance as a result of Covid-19 analysis

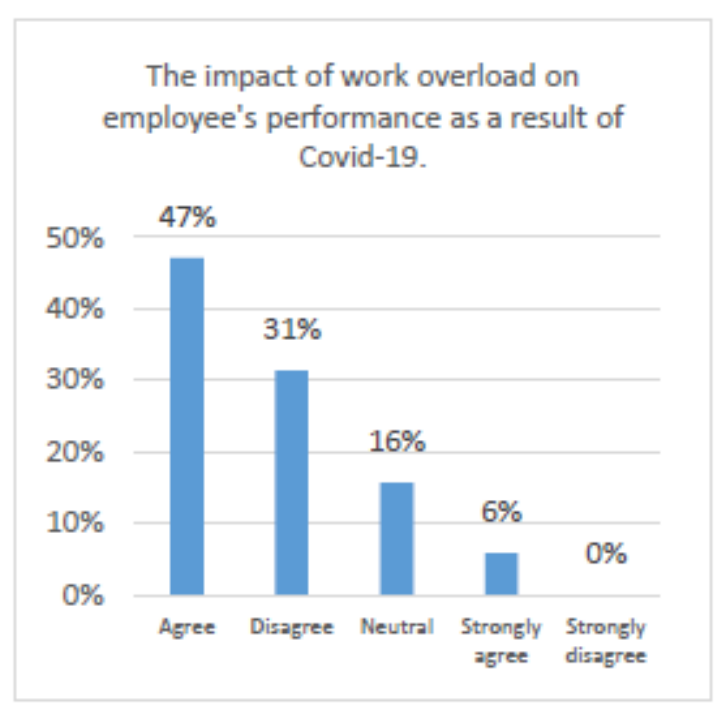

Figure 15. The impact of work overload on employee's performance as a result of Covid-19 analysis

\section{Conclusion}

The main purpose of the study was to examine the perception of employees of one of the private banks in Egypt and their performance in the presence of job stress in the uncertain period of the coronavirus pandemic. There were three job stressors understudy: role ambiguity, underutilization of skills, and work overload. Also, the impact of Covid-19 on these job stressors was studied. From the analysis, it is found that there is a potential for disagreement that role ambiguity and underutilization of skills have an impact on employee performance, while work overload was found to have an impact on employee performance. In terms of the effect of the Covid-19 Pandemic, most of the respondents found that role ambiguity has no impact on employee performance while regarding underutilization of skills respondents were neutral neither agree nor disagree. On the other hand, it was found that respondents agreed that work overload has an impact on employees' performance in this very stressed period of the pandemic.

\section{Recommendations}

According to the findings of this paper, it is recommended that banks need to find ways to manage the stress and minimize the work overload of their employees in order to enhance employees' performance levels. This may include taking into consideration the development of employees' skills in order to reach their maximum level of performance. Moreover, managers and supervisors could provide more opportunities for employee growth or progression. Also, the HR department requires to identify the talents and potentials of employees before 
assigning tasks to avoid overload of work. Finally, the appraisal and promotion system must have a proper way to provide feedback, set goals, communication skills, recognition, and task assignment.

\section{Further Research}

There are a lot of job stressors other than the ones under study that need more investigations as role conflict, conditions of work, physical, lack of motivation, communication, work-life balance, time pressure, the riskiness of job, and others. Thus, it is recommended to study whether these factors have an impact on employee performance in the banking sector in Egypt, especially in the COVID-19 era.

\section{References}

Abu-Hussein, A. H. M., Abu-Salih, M. S., \& Al Saket, L. Z. (2016, May). Impact of Job Stress on Job Performance. Research Journal of Social Sciences, 1-9.

Amr, M., El-Gilany, A. H., El-Moafee, H., Salama, L., \& Jimenez, C. (2011). Stress among Mansoura (Egypt) baccalaureate nursing students. Pan African Medical Journal. https://doi.org/10.4314/pamj.v8i1.71083

Anderson, R. (2003, June). Stress at work: the current perspective. The Journal of The Royal Society for the Promotion of Health, 81-87. https://doi.org/10.1177/146642400312300211

Bashir, U., \& Ramay, M. I. (2010). Impact of stress on employees job performance a study on banking sector of Pakistan. International journal of marketing studies, 2(1). https://doi.org/10.5539/ijms.v2n1p122

Boots, A. A. (2019). Most Stressed Countries in the World. Retrieved from https://www.atlasandboots.com/most-stressed-countries-in-the-world/

Bower, E. (2016, October). The growing problem of stress in the workplace. The American Chamber of Commerce in Egypt.

Chinyere, M. P., Ngige, C. D., \& Mojekeh, M. O. (2019, May ). Effect of job stress on employee performance in selected banks in Nigeria Mbanefo Priscilla. Scholars Journal of Economics, Business and Management, $55-62$.

Elsabaa, A. Y. (2020, October 27). اللبورصة تعلن تنفيذ عرض الثراء الإجبار على بنك الأهلى الدتحد بـ913 مليون جنبه. Retrieved October 28, 2020, from https://www.youm7.com/story/2020/10/27/5039960/البورصة_تعلن-تنفيذ-عرض-الثر اء_الإجبار _على_بنك_الأهلى_المتحد

ElSafty, A. (2018). Business Research Methods. Egypt: Lecture Notes, Lecture One.

Elsafty, A. (2018). Lecture 2: Scientific Business Research Problem Definition [PowerPoint slides]. Retrieved from Maastricht School of Management, MBA Degree.

Elsafty, A. (2018). Lecture 2: Scientific Business Research Problem Definition [Lecture]. Retrieved from Maastricht School of Management, MBA Degree.

Elsafty, A. (2020). DrAshrafElsafty Channel. Retrieved from https://www.youtube.com/watch?v=y-jDT2iOOhU\&list=PLKSWZdnzp8p3uFLLh2N8_d0W7ZmJDLMjW \&index $=42 \& \mathrm{t}=628 \mathrm{~s}$

Elsafty, A., \& AlNawaly, A. (2020). Role of Co-Working Spaces' Services in Entrepreneurs Growth in Upper Egypt, The Case of Step Co-Working Space. Business and Management Studies, 6(2). https://doi.org/10.11114/bms.v6i2.4899

Elsafty, A., \& Elshahed, M. (2021). The Changes in Online Buying Intention as a Determinant of Behavior During COVID-19 Pandemic in the Ready-Made Garments Industry in Egypt. International Journal of Business and Management, 16(5), 1-24. https://doi.org/10.5539/ijbm.v16n5p1

Elsafty, A., \& Elzeftawy, A. (2021). The New Era of Digital Transformation and COVID-19 Effect on The Employment in Mobile Operators in Egypt. Business and Management Studies, 7(1), 1-21. https://doi.org/10.11114/bms.v7i1.5087

Elsafty, A., \& Osman, M. (2021). The Impact of COVID-19 on the Efficiency of Packing Lines in Pharmaceutical Manufacturing Sites in Egypt. International Journal of Business and Management, 16(7), 57-72. https://doi.org/10.5539/ijbm.v16n7p57

Elsafty, A., \& Ragheb, M. (2020). Role of Human Resource Management towards Employees Retention during Covid-19 Pandemic. Business and Management Studies, 6(2). https://doi.org/10.11114/bms.v6i2.4899

Elsafty, A., \& Tahon, A. (2020). Exploring Impact of Corporate Social Responsibility on Organizational 
Performance, the Case of Turkish Islamic Banks. Business and Management Studies, 7(1), 1-21. https://doi.org/10.11114/bms.v7i1.5087

Elsafty, A., Abadir, D., \& Shaarawy, A. (2020). How Does the Entrepreneurs' Financial, Human, Social and Psychological Capitals Impact Entrepreneur'S Success? Business and Management Studies, 6(3), 55-71. https://doi.org/10.11114/bms.v6i3.4980

Elsafty, A., Elbouseery, I., \& Shaarawy, A. (2020). Factors Affecting the Behavioral Intention to Use Standalone Electronic Personal Health Record Applications by Adults in Egypt. Business and Management Studies, 6(4), 14-36. https://doi.org/10.11114/bms.v6i4.5066

Elsafty, A., Elsayed, H., \& Shaaban, I. (2020). A Business Analysis Perspective for Engineering Education in Egypt. Journal of Education and Training Studies, 8(5), May 2020. ISSN 2324-805X E-ISSN 2324-8068. https://doi.org/10.11114/jets.v8i5.4721

Elsafty, A., Elsayed, H., \& Shaaban, I. (2020). Educating Engineering Students in Egypt: Recommendations for Improvement. International Journal of Higher Education. https://doi.org/10.5430/ijhe.v9n3p1

Elsafty, A., Elsayed, H., \& Shaaban, I. (2020). Journal of Education and Training Studies, 8(8). https://doi.org/10.11114/jets.v8i8.4901

Foster, L. B. (2002). Workplace stress: Changing the pattern. Sales and Marketing Journal, 32-33.

Gatway, S. (2020, Jan). Kuwait Finance House shareholders approve acquisition of Bahrain's Ahli United Bank. Retrieved from https://salaamgateway.com/story/kuwait-finance-house-shareholders-okays-bahrains-ahli-united-bank-acqui sition

Gavidia, M. (2020, April 21). How Has COVID-19 Affected Mental Health, Severity of Stress Among Employees? Retrieved from https://www.ajmc.com/view/how-has-covid19-affected-mental-health-severity-of-stress-among-employees

Giorgi, G., Arcangeli , G., Perminiene, M., Lorini , C., Ariza-Montes, A., Fiz-Perez, J., ... Mucci, N. (2017, December 12). Work-Related Stress in the Banking Sector: A Review of Incidence, Correlated Factors, and Major Consequences. Frontier in Psychology. https://doi.org/10.3389/fpsyg.2017.02166

Goswami, T. G. (2015). Job stress and its effect on employee performance in banking sector. Indian Journal of Commerce \& Management Studies, 5(2), 51-56.

HSSE, H. S. (2001). Work-Related Stress short guide. Retrieved from https://hsseworld.com/work-related-stress-short-guide/

J., A. (2014). Determinants of employee engagement and their impact on employee performance. International Journal of Productivity, 63(3), 308-323. https://doi.org/10.1108/IJPPM-01-2013-0008

Jalagat, R. (2017, January). Determinants of Job Stress and Its Relationship on Employee Job Performance. American Journal of Management Science and Engineering, 2(1), 1-10. https://doi.org/10.11648/j.ajmse.20170201.11

Jamshed, K. K., Khan, M. A., Haq, A. U., Arif, M., \& Minhas, A. A. (2011, February 4). Occupational stress and burnout in Pakistan's banking sector. African Journal of Business Management, 5(3), 810-817.

JC, C., \& C., S. (2008). The impact of locus of control on job performance and job satisfaction in Taiwa. Leadership \& Organization development journal, 572-582. https://doi.org/10.1108/01437730810906326

M.Kotteeswari, \& Sharief, D. (2014). Job Stress and its impact on employee's performance. A study with reference to employees working in BPOS. International Journal of Business and Administration Research, 2(4), 18-25.

Madian, A. A. A., Abdelaziz, M. M., \& Ahmed, H. A. (2019). Level of Stress and Coping Strategies among Nursing Students at Damanhour University, Egypt. American Journal of Nursing Research, 7(5), 684-696. https://doi.org/10.12691/ajnr-7-5-3

Margolis, B. L., Kroes, W. H., \& R. P. (1974). Job stress: An unlisted Occupational Hazard. Journal of Occupational Medicine, 1(1), 659-661.

Mayer, K. (2020, April 14). HRE's number of the day: Coronavirus stress. Retrieved from https://hrexecutive.com/hres-number-of-the-day-coronavirus-stress/

Muda, I., Rafiki, A., \& Harahap, M. R. (2014). Factors Influencing Employees' Performance: A Study on the 
Islamic Banks in Indonesia. Indian Journal of Commerce \& Management Studies, 5(2), 73-80.

Murali, S. B., Basit, A., \& Hassam, Z. (2017, November). IMPACT OF JOB STRESS ON EMPLOYEE PERFORMANCE. International Journal of Accounting \& Business Management, 5(2), 13-33.

News, D. (2007, May 30). Ahli United Bank purchases Delta International. Retrieved from https://dailynewsegypt.com/2007/05/30/ahli-united-bank-purchases-delta-international/

Pandey, D. L. (2020, May). Work Stress and employee performance: An assessment of impact of work stress. International Research Journal of Human Resource and Social Sciences, 7(5), 2394-4218.

Rahman, M. H. (2013). Job stress-employee performance and health: A study on commercial bank in Bangladesh. Global Journal of Management and Business Research Economics and Commerce, 13(4).

Rizwan, M. (2014). Investigating the Causes of Job Stress: A Study on Banking Sector of Bahawalpur, Pakistan. International Journal of Learning \& Development, 4(2), 227. https://doi.org/10.5296/ijld.v4i2.6099

Robbins, S. P., Coutler, M., Sidani, Y., \& Jamila, D. (2011). Management (Arab world edition ed.). England: Pearson Education Limited.

Sabir, R. I., Akhtar, N., Zakir, U., Nadeem, I., \& Rehman, A. U. (2014). Influential factors on job stress and its effect on the employee's performance among bank sepah branches in tehran. Journal of Asian Business Strategy, 58-73.

Salim, M. E., Abdel Wahed, A. S., Zidan, O. O., \& Aboal asaad, M. M. (2019). Occupational Stress among Banking Employees at El Mansoura City. The Egyptian Journal of Hospital Medicine, 4445-4451. https://doi.org/10.21608/ejhm.2019.44526

Shahid, M. N., Latif, K., Sohail, D., \& Ashraf, A. M. (2010). Work stress and employee performance in banking sector evidence from district faisalabad, Pakistan. Asian Journal of business and management sciences, 1(7), 38-47.

Silva, L. S., \& Barreto, S. M. (2012). Stressful working conditions and poor self-rated health among financial services employees. Rev Saúde Pública. https://doi.org/10.1590/S0034-89102012005000023

Singh, S. (2020, Sept 11). Workplace Stress and Anxiety After COVID-19. Retrieved from business.com: https://www.business.com/articles/workplace-stress-anxiety-covid-19/

Vijayan, M. (2017, July). Impact of job stress on employees' job performance in AAVIN, COIMBATORE. Journal of Organisation \& Human Behaviour, 6(3), 21-29.

WHO. (2020, March). Coronavirus disease (COVID-19) pandemic. Retrieved from World Health Organisation (WHO): https://www.who.int/emergencies/diseases/novel-coronavirus-2019 


\section{Appendix (A)}

Questions of the questionnaire

\begin{tabular}{|c|c|c|}
\hline Variables & variable de & Questions \\
\hline \multirow{9}{*}{ 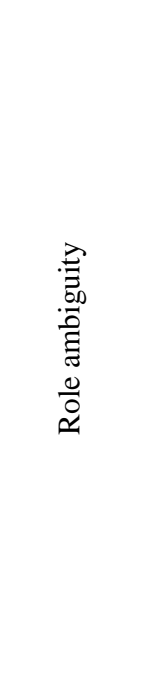 } & \multirow{9}{*}{$\begin{array}{c}\text { Stress could occur } \\
\text { when employees do not } \\
\text { have a clear role or } \\
\text { responsibilities of what } \\
\text { is required from them } \\
\text { (Jalagat, 2017). }\end{array}$} & 1. The department's objectives are not clearly stated. \\
\hline & & 2. My job needs too much effort and support which are not available to me. \\
\hline & & $\begin{array}{l}\text { 3. I am under stress most of the time due to unclear procedures that could affect my } \\
\text { performance. }\end{array}$ \\
\hline & & 4. This company really deprives the best in me because of role confusion. \\
\hline & & $\begin{array}{l}\text { 5. I feel that everyone prefers to enforce themselves with regards to their perceived } \\
\text { individual roles than following what should be their organizational roles. }\end{array}$ \\
\hline & & 6. I feel that it is difficult to create a clear path that I need to do with \\
\hline & & 7. I don't have sufficient input in determining my work-unit goals. \\
\hline & & $\begin{array}{l}\text { 8. The structure of my work units is not clear which reduces my contribution in } \\
\text { enhancing the organizational performance. }\end{array}$ \\
\hline & & 9. I am often confused in setting the priorities of tasks to be \\
\hline \multirow{3}{*}{ 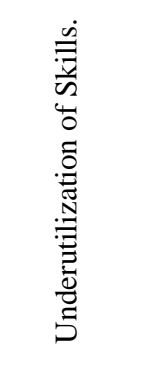 } & \multirow{3}{*}{$\begin{array}{l}\text { Stress could occur } \\
\text { when the skills and } \\
\text { abilities of the } \\
\text { employees are } \\
\text { exceeding and beyond } \\
\text { the job requirements } \\
\text { (Jalagat, 2017). }\end{array}$} & 10. My job does not offer me the opportunity to grow as a person. \\
\hline & & 11. I felt that I can achieve more than predictable but I am not given chances. \\
\hline & & 12. I feel that my knowledge, skills and abilities will stagnate as long as I am here. \\
\hline \multirow{4}{*}{$\frac{\pi}{\stackrel{0}{0}}$} & \multirow{4}{*}{$\begin{array}{l}\text { Stress could occur } \\
\text { when employees are } \\
\text { overloaded with work } \\
\text { that exceed their } \\
\text { capability of executing } \\
\text { it (Jalagat, 2017). }\end{array}$} & $\begin{array}{l}\text { 13. I am responsible to achieve too many tasks which affect my concentration and } \\
\text { performance. }\end{array}$ \\
\hline & & $\begin{array}{l}\text { 14. I would accept almost any type of job assignment even if I feel tired in order to } \\
\text { maintain my performance at higher level. }\end{array}$ \\
\hline & & 15. Lack of support of my colleague in finishing many tasks affects my performance. \\
\hline & & 16. I am involved in various responsibilities and hold too many roles. \\
\hline \multirow{4}{*}{ 官 } & \multirow{4}{*}{$\begin{array}{l}\text { Coronavirus pandemic } \\
\text { has resulted in increase } \\
\text { of the level of job stress } \\
\text { for employees and this } \\
\text { could affect their } \\
\text { performance }\end{array}$} & $\begin{array}{l}\text { 17.I feel that it is difficult to create a clear path that I need to do with my job due to } \\
\text { COVID-19. (Role ambiguity) }\end{array}$ \\
\hline & & $\begin{array}{l}\text { 18. I felt that I can achieve more than predictable but I am not given chances due to } \\
\text { COVID-19. (Underutilization of skills) }\end{array}$ \\
\hline & & $\begin{array}{l}\text { 19. I am responsible to achieve too many tasks which affect my concentration and } \\
\text { performance especially in COVID- } 19 \text { period. (Work overload) }\end{array}$ \\
\hline & & COVID-19. \\
\hline
\end{tabular}

\section{Copyrights}

Copyright for this article is retained by the author(s), with first publication rights granted to the journal.

This is an open-access article distributed under the terms and conditions of the Creative Commons Attribution license (http://creativecommons.org/licenses/by/4.0/). 